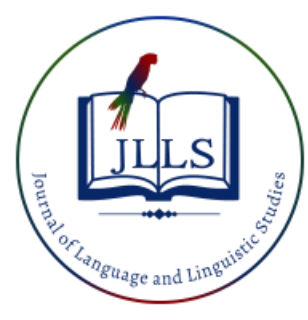

Available online at www.jlls.org

JOURNAL OF LANGUAGE

AND LINGUISTIC STUDIES

ISSN: $1305-578 \mathrm{X}$

Journal of Language and Linguistic Studies, 17(3), 1536-1550; 2021

\title{
Teaching of literature in the EFS/ESL classrooms: An effective tool to instil moral values
}

\author{
Mohammad Mujtaba Ahmad ${ }^{\text {a } 1 \text { iD }}$ \\ ${ }^{a}$ Methnab, Qassim University, Kingdom of Saudi Arabia
}

\section{APA Citation:}

Ahmad, M. M. (2021). Teaching of literature in the EFS/ESL classrooms: An effective tool to instil moral values, 17(3), 1536-1550. Doi: $10.52462 / \mathrm{jlls} .111$

Submission Date:28/05/2021

Acceptance Date:25/08/2021

\begin{abstract}
The place of literature in the ELT classroom has been investigated by different scholars across languages. It is also a debatable issue, but many are of the belief that it plays a great role in the acquisition and learning of Language skills: listening, speaking, reading and writing. While literature claims that poetic justice prevails in the end, the passage goes through waywardness which is the way of the world with evil doers stealing the limelight while goodness and fairness are side-lined by the majority. In this scenario, the role of educational institutions is one of great responsibility in producing men and women who pose unwavering faith in human and moral values. Human society badly needs education that teaches moral lessons. Literature plays a vital role in educational curricula to ensure the imparting of the finer values of humanity, and this is also why literature finds a place, however small, in all course curricula. This study streamlines the role of literature in EFL/ ESL classrooms in instilling moral values to save humanity from degradation and decadence.
\end{abstract}

Keywords: Teaching; EFS/ESL Classrooms; Moral Values; literature; Effective; Instil

\section{Introduction}

A Chinese proverb reads, 'There is hardly any book that has nothing in it', suggesting that something or the other will be gained from reading any book whatsoever. But it is equally important to remember these words of Francis Bacon that' some books are to be tasted, others to be swallowed, and some few are to be chewed and digested. Of course, there are books that are trendsetters and have epoch-making values. Milton's Paradise Lost, which justifies the ways of God to man and essays of Bacon, Shakespeare's plays, novel of Hardy and Dickens, and Eliot's Waste Land are the pride of literary corpora. Through such books in EFL/ESL classrooms, educational institutions can ensure the development of trustworthiness, respect, responsibility, justice and fairness, caring, civic virtue, and citizenship amongst the learners (Akin, 1995). Since the invention of letters, literature has played a crucial role as a moral guide and other functions like enjoyment and diversion. Books are a great way of upholding ethics and depicting the human condition in a global perspective.

\footnotetext{
${ }^{1}$ Corresponding author.

E-mail address:1933@qu.edu.sa
} 


\section{Literature Review}

Literature plays an essential role in teaching language skills. However, when utilizing literature in the language classroom, language skills should never be taught in isolation but in an incorporated way (Hişmanoğlu, 2005; Khan \& Alasmari, 2018). Teachers must strive to teach basic language skills as an integral part of oral and written language use. Learners can find a range of individual lexical or grammatical items in literature. Many aspects of written language, intrinsic reading and a body of contextual text become known to students. Grammar and speech functions are taught to them. Sentences, the various structures that might be used, and the various ways of connecting concepts are all examples of this.

Litereture improves and expands students writing abilities. As a language learner, literature has several advantages worth noting. In addition to syntax and lexis, the literature contains pragmatic and cultural elements that are difficult to find in non-literary texts. Since literature is full of examples of real-life language in various situations, Van (2009) states that it provides unprecedented opportunities to explore the use of real-life idioms and phrases in literature. Several scholars, such as (Muhammed 2013; Khan \& Alasmari, 2014; Khan, 2014) claimed that it is vitally essential to teach students literature. Literature always has a powerful language and contains the skills needed for language learning. Human beings tend to interpret things and ideas; this activity can be enhanced through reading, a skill that literature serves to achieve (Collins, 1993). According to Hişmanoğlu,(2005), teaching English literature provides authenticity to language learning. Moreover, literature will assist learners in improving their language skills considerably.

\section{Methodology}

The researcher followed the descriptive approach. This study authenticates the comprehensiveness of utilizing literature to learn and teach English language to EFS /EFL learners. It clarifies how different language skills can be acquired effectively. This paper demonstrates the importance of literary texts in teaching the English language. In this study, the historical background of using literature in instruction is explored. It deals with several pioneer poets, scholars, and philosophers who have contributed significantly to human instruction throughout history. It tried to find out the merits of these great scholars to be ustilized in the morally fragemented world.

\section{Moral Values and Literature}

\subsection{Milton to Shakespeare}

With the invention of the printing press as a result of the Industrial Revolution, literature became available to the masses whereas earlier, it was limited to the domain of the elite or intellectual class. A deep study of the history of English literature shows that literature from the beginning has had a tendency to be laden with moral values that lead the human race in various walks of their lives. However, sometimes artistic compulsion forces writers to present evil characters in such a forceful manner that they gain popularity among the readers. This has invited the wrath of critics for instance, Milton's presentation of Satan in Paradise Lost is almost as a hero has often invited the remark that a writer should be more careful to instruct than to please. Moreover, representational art is strewn with illustrations of violence, forcing critics to hold that morals, rectitude, and literary excellence are different things, and that aesthetic considerations and morals are not similar but not altogether different either. It is important to note the famous remark of Socrates about literature, which according to him, is nothing but imitation of an imitation since poetic representation leads us away from truth. Literature, at times, draws us to the mere sensation as a result of which the unruly emotions victimise 
us. It is precisely against this that Johnson warns us when he emphasizes on inculcation of virtue in literature in his famous essay in the Rambler: 'It is justly considered as the greatest excellency of art to imitate nature; but it is necessary to distinguish those parts of nature which are most proper for imitation: greater care is still required in representing life, which is so often discolored by passion or deformed by wickedness. If the world is promiscuously described, I cannot see what use it can be to read the account.'Though Shakespearean plays are not free from scenes of violence that led the puritans of the time to declare the theatre blasphemous, their artistic excellence surpassed all such considerations, and Shakespeare's work is said to hold the mirror of manner and life. Shakespeare explored typical humans who were the models for their profession, bringing to the readers, the human weakness, whether in comedy or tragedy. A study in the case is The Merchant of Venice, which is nothing if not a lesson in morality rooted in the tenets of the Old Testament (an eye for an eye, a tooth for a tooth) that Shylock insists on. The work explores the limits of human dignity, wit, and humility.

Similarly, in his tragedies, he has explored the imperfections of human nature. His first great tragedy Romeo and Juliet depicts the hypocrisy and bigotry of the society where family feuds, social injustice, and the community's indifference are the harbingers of tragedy for the young couple. Jealousy, distrust, revenge, and vulnerability are the high points of human frailty in Othello. Iago is the perfect villain who never commits a crime himself but manages to have it executed by people around him, playing upon their emotional states. King Lear depicts an egotist king who is given to flattery, unable to differentiate between good and evil. Though King Lear is one of the most grotesque and violent plays with murders, blinding, and battles, Shakespeare has creatively dealt with human imperfections in the play. Thus, Justice, truth, morality, and identity are central to Shakespeare's works which encompass all facets of human nature, positive and negative, touching equally upon villainy and courage, virtue and egotism, generosity and greed, valor, and deceit.

\section{Mathew Arnold}

Arnold began his career as a poet, but he turned to prose in the later years of his life. What is now known as cultural criticism was inaugurated by him. In his book Culture and Anarchy, he strongly defended literature, especially the classical literature now known as the literature of the elite, considered as the basis of civilized society. Arnold believed in the humanist view of literature and held that culture was the 'best that has been thought and said.' He was a cultural critic and his contribution to the cultural criticism can be understood under three significant titles:

1. Ethical idealism which held that ethical considerations should have humanistic tools, not the religious foundation.

2. True Education as a matter of national concern.

3. Insistence on the formative nature of literature.

It is important to include here the famous remark of Eliot about the religious and ethical stand of Arnold on literature as 'degradation to moral anarchy' while some other critics went to the extent of describing his ethics as a 'prophetic vision of a new Christian faith.' His opinion was not in line with Catholic theology of metaphysical knowledge and protestant inspiration. According to Robbins (1959, pp.172-178) for Arnold 'ethical cultural societies' and an emphasis on 'regenerative principles' in the transmission of cultures is 'to know the best that has been said and thought in the world'. Arnold had first-hand experience of the developing morality in his time as he worked as a school inspector and investigated the education systems in several European nations. He departed from the divinelyinspired morality and advocated moral instruction in education. He advocated in his school reports the need to moralise humanity and also advocated in favour of humanizing the power of poetry. In his opinion, great literature was a source of peoples' aspiration for the highest ideals. 


\subsection{T. S. Eliot}

Eliot was one of the most complex poets of the $20^{\text {th }}$ century. He was a powerful advocate of moral education in educational institutions and firmly believed that a reader's personality is invaded by the personality of an author. In Religion and Literature (1932) Eliot is critical of the liberal attitudes towards literature which 'got corrupted by secularism'. Eliot (1932) believed in the strong moral power of literature, 'in the moral power of literary work in affecting, albeit mostly negatively, our whole being was so strong, as to claim that no book was harmless - with the exception of ones' so utterly unreadable as to be incapable of injuring anybody.

\subsection{Canonical Literature and Ideology}

The American Heritage Dictionary defines literary canonas "an authoritative list, as of the works of an author" and "a basis for judgement ; a standard; or criterion" and as such it invokes a certain prestige and accessibility to public consumption (AHD). Authors of great repute like Shakespeare, Milton, Wordsworth are said to hold this status. Authors like Fitzgerald are prime examples of this type as his novel The Great Gatsby is a true reflection of the American society during the 1920s. These canonical text perpetuate ideologies dominant about whiteness, masculinity, heterosexuality, Christianity. It is interesting to note that in canonical literature, the domination of white male and bourgeois authors and ignorance of non-white, women have also been a bone of contention. But some female writers of great repute like Virginia Woolf, Jane Austen and Emily Dickinson have produced literature that is considered as canonical. Since the $20^{\text {th }}$ century these female authors are being taught in Western Universities across Europe.

Literary works are canonised for the following reasons:

1. Ideological values: Smith (1988) says, " those with cultural power tend to be members of socially, economically, and politically established classes (or to serve them and identify their own interests with theirs), the texts that survive will tend to be those that appear to reflect and reinforce establishment ideologies.

2. Aesthetical values: Bloom (1987) observes, "the aesthetic choice has always guided every secular aspect of canon formation".

All great works of literature stood the test of time and there is no reason to consider those as canonical and ideological literature which failed this test and slid into oblivion. Hume (Hume,1990) supports this criterion by citing the example of Homer whose Iliad has been read generation after generation. According to Marx, the literary value of a work of art may be the result of a particular social condition at a particular period of time, but it is most important that it stand the test of time. It's the longevity and qualities that engage the interest of people from generation to generation that remain the essential criteria for any literature to be labelled as canonical. It may not be out of context to note what the critics of the Eurocentrism view of the canon have to say about it as a list of books by 'dead Europeans- Shakespeare, Dante, Tolstoy, Dostoevsky, Stendhal, Donne- that are bound to implant a permanent bias towards other culture.' (Pantić, 2006). Hughes, however, (1993) provides some reasonable arguments against such judgements. He says, "criticism is based on an oversimplifying assumption that we necessarily become what we read", (p.98), or in his words, 'Imbibe the Republic or Phaedo at nineteen and you will be one kind of person; study Jane Eyre or Mrs Dalloway or the poetry of Aphra Behn, and you will be another' (Pantić, 2006). He suggests that we can't see other cultures well, until through knowing our own we 'reach a point where inclusiveness means nothing'. Otherwise, we will be left with "mere indecisive mush". We can't deny the role of great writers of 
canonical literature simply because they are not the citizens of this age. Their excellence in the creation of characters that play the role of a moral guide should be valued.

\subsection{Aestheticism and Didacticism}

\subsubsection{Aestheticism}

Aestheticism is a movement that started in England and France in the $19^{\text {th }}$ century. It championed the slogan 'art for art's sake.' Victor Cousin, Oscar Wilde, Walter Peter, and the Rossetti were its strong supporters. The believed that the primary function of art was aesthetic and sensual, not intellectual or moral. Its aim was 'to please the senses rather than convey an argument.' (Nayar, 2009). Excessive use of symbols and imagery was accordingly, encouraged. Wilde even coined an aesthetic slogan 'life imitates art'. Poets and actors are drawn to what is lurid and sensational. The word aesthetic is derived from the Greek word aistheta, 'things perceived by senses'. It supports the aesthetic values and effects in comparison to socio-political themes and positions. The artists and writers belonging to aesthetic styles tended to admit the plea that arts should provide refined sensuous pleasure, rather than convey moral or sentimental messages. They didn't believe in the didactic function of art. The cult of beauty was the basic factor of art. Predecessors of the aesthetics were Keats and Shelley and some of the pre- Raphaelites who were a legacy of the Romantic spirit.

\subsubsection{Didacticism}

Didactic art is meant to instruct and entertain. Didactic plays, for example, convey a moral theme or other rich truth to the audience. This term has its origin in Greek didaktikos related to teaching Alexander Pope's An Essay on Criticism which provides a lots of advices to critics. Indeed criticism is an example of didacticism. It advocates instructional and informative qualities in literature.

Having briefly discussed aestheticism and didacticism, it is important to note what Shelley wrote in "Defence of Poetry":

Poets, or those who imagine and express this indestructible order, are not only the authors of language and of music, of the dance and architecture and statuary and painting; they are the institutions of laws and the founders of civil society and the inventers of the arts of life and the teachers, who draw into a certain propinquity with the beautiful and the true that partial apprehension of the agencies of the invisible world which is called religion... It would be an extreme view to deny the role of moralizing to literature because of its aesthetic qualities. Great works of literature give us delight but this is not the end of the road. In Paradise Lost, Milton has portrayed the character of devil in such a mighty way, and the words spoken by devil are so powerful that at times it seems appropriate to think that Milton belongs to the devil's party. But it's a well-established fact that Milton was a religious man and his purpose of writing Paradise Lost was to justify the ways of God to man. So, on aesthetic grounds, literature can't be denied from possessing a moralizing role.

\subsection{Ethical Dimension of Literature}

It is a well-established fact that the relation between literature and values has undergone changes down the ages. Some critics and scholars say that the two are inseparable while there are some others who don't endorse this view. Moral values and art or ethics and aesthetics are the two sides of the river. Wilde in the preface of his novel The Picture of Dorian Gray says, 'No artist has ethical sympathies. An ethical sympathy in an artist is an unpardonable mannerism of style.' But this extreme view about aesthetic failed to garner general support even in his time. It was also a challenge to the views of the Victorians about the function of literature. 'In the heyday of poststructuralism and postmodernism, widespread agreement prevailed again, but amidst an era of poststructuralist relativism, readers and writers, publishers and critics seemed to agree that the realms of literature and 
the study of bad and good characters. Literary texts indirectly disseminate values. There are certain morality were indeed two entirely separate spheres' (Baumbach et al., 2009). The weight of traditional values can be felt in the poststructuralists and constructivists to the extent that common truths are constructed culturally. Through narratives and fictional worlds, we are sensitised to ethical questions and moral inquiries. Literature and media give us incentives to be engaged in ethical discourse through techniques which are very effective so far as garnering of values is concerned. Narrative technique is found to be helpful for ethical and moral implication. In this context, Müller (2008) held that narrative technique and point of view carried intensive ethical implication. The following narration are important in this concern.

1. Authorial narration

2. Point of view narration

Literature represents the existing values and norms. It also constructs new values and norms and, at times, it disseminates these norms and values. To simplify these points one can remember the following functions of literature:

1. Pre -figuration (extra-literary reality): norms and values existing in the real world and the norms and values created

2. Configuration

3. Refiguration

Literature, in a very significant way, forms and stabilizes new values and norms and conceptions of a better living. Literature is seen as a medium of the representation of extra-literary norms and values that can generate and construct new values and norms. It can also serve as a medium to disseminate norms and values. Finally, literature has power to serve as the medium to construct new values and norms.

\subsection{Universal Moral Values}

In the ever-growing pluralistic society of our times, with numerous cultures, languages, and ethnic groups, it is difficult for educators to decide what values qualify to be taught. 'Today educators are not so worried about "whose values to teach," and are acknowledging this fact that every person needs to acquire certain character attributes and needs to be guided by universal moral values- values that unite all people everywhere because they affirm basic human worth and dignity' (Akin, 1995,). Universal moral values underlined in the 1948 United Nations Universal Declaration of Human Rights states the following points:

1. Life

2. Freedom from personal attack

3. Freedom from slavery

4. Recognition before the law and the presumption of innocence until proven guilty

5. Freedom from torture

6. Freedom of conscience and religion

7. Privacy, family, and correspondence

8. Freedom to participate freely in community life

9. Education

10. A standard of living adequate for maintaining health and well being 
The teaching of literature everywhere may prove to be a boon to learn the above mentioned moral values. Besides these there are six core moral values which are labelled as attributes of character are outlined in (Akin, T. (1995; Al-Ahdal, 2020; Mohaideen et al.,2020; Hazhar, 2021):

1. Trustworthiness

2. Respect

3. Responsibility

4. Justice and Fairness

5. Caring

6. Civic Virtue and Citizenship

All these moral values have literary connections. Through the study of literature these moral values are learnt in an indirect manner or direct manner. Akin, T. (1995)) talk about the following human values under the title 'The Six Pillars of Character':

1. Trustworthiness

Worthy of trust, honour, and confidence

Honesty: trustful, sincere, nondeceptive, candid, not cheating

Integrity: morally courageous, principled

Promise-keeping: dependable, reliable

Loyalty: faithful, allegiant, supportive, maintains confidences

2. Respect

Regard for dignity, worth and autonomy of all persons (including self)

Treaty others with courtesy, civility, politeness

Tolerating other's beliefs

Accepting individual differences without prejudice

Refraining from violence, coercion, intimidation

3. Responsibility

Acknowledgement and performance of duties to others and self

Accountability: answerable for consequences of decisions

Pursuit of excellence: diligent, perseverant

Self-discipline: self-control, restraint

4. Justice and Fairness

Making decisions on appropriate factors: impartiality, avoidance of conflicts of interest

Commitment to equity and equality

Openness to information and ideas

Reasonableness

Due Process

Consistency

Fair Play 


\section{Caring}

Regard for the well-being of others

Kindness

Compassion

Consideration

Unselfishness

Charity: altruism, giving

6. Civic Virtue and Citizenship

Recognition of and living up to social obligations

Law abidance

Protection of environment

Community service

Doing one's share

\section{Selective Functions of Literature to Instil Moral Values}

Literature serves numerous functions that help us in making our life fulfilling. It is a tonic for the weeping humanity, a messenger of peace and love, a guide to face different challenges that the modern life presents. It gives us delight, refreshes the mind, removes boredom. In addition to all these functions of literature it is highly useful for the development, comprehension, understanding, and evaluation of English language, but here we are primarily concerned with the values that literature carries. Literature is a balm in modern times. It broadens our outlook and gives us wider human experience. Though literature refers to the real world in an indirect way and this real world in which we breathe, and the story world or the imaginative world in novels, poems, plays and other genres of literature vary, yet it is an admitted fact that literature has conjuring and generating powers. The story world and the atmosphere created in books of literature serves as a model for thought and feeling. If we rely purely on the function of literature in the light of models found in the literary work, we may not be able to admire the cultural functions of literature. Discussing the cultural function of literature in an article entitled 'Literature and Values' Baumbach et al. (2009) have cited from the Zapf (2006, p.85) a tripartite model of the cultural- ecological function of literature:

1. Literature not only represents but also balances, lays bare, and critiques typical contradictions, deficits, and deformations displayed by the economic, political, and social systems of a given society. By doing so, literature fulfils "the function of a cultural-critical meta-discourse."

2. Literature confronts society with alternative or possible story worlds that serve to put the dominant world models into perspective. Zapf's term for this is "the function of an imaginative counter-discourse".

3. Literature serves to confront that which is marginalised or repressed in a given system with the hegemonic world view and to synthesize or reintegrate the various discourses that are usually separated in society. (e.g., the discourses of the systems of politics, economics, law, education etc.), thus fulfilling "the function of a reintegrative inter-discourse".

In addition to the above mentioned cultural functions, literature is known for its normative functions. It disseminates, and represents new values and norms. However, the values projected in literary works and the values prevalent in society may vary. Literature can serve the critical functions 
also. Some norms and values of society are criticized by literary work that results in the creation of new norms and values.

So, literature works on different levels: emotional, ideological, normative, and logical. Special mention must be made of fictions and novels in establishing norms, setting trends, exposing social follies. highlighting corruption and producing soothing and allaying effects upon tormented heads and hearts.

\subsection{Morals in Sundry Genres of Literature}

From time immemorial to the recent age, moral values are taught in one way or another. All religious book, be it the Holy Qur'an, the Old or New Testament, or the Bible, are moral guides. They teach the ways of God to men. After the invention of the printing press by Caxton in $14^{\text {th }}$ century lots of literary books came into existence and slowly, but gradually literary works stole the public imagination and also became a didactic tool to teach moral lessons. Eliot (1932) criticizes liberal attitudes towards literature. He believed in the great formative power of literary books. As a matter of general experience, in every EFL/ESL class, students are taught different genres of literature, so it seems productive to study some genres of literature with examples to establish the fact that literature works as a great carrier of moral lessons and its effect on students throughout the world is strongly felt. Let us examine poems, short stories and some Elizabethan and Victorian plays along with some great novels to decipher the moral values prevalent in them.

1. Poems: In most of the EFL/ESL poems strong moral lessons are taught. The following poem of Thomas Hardy may be a good example of this.

\section{The Man He Killed}

Had he and I but met

By some old ancient inn,

We should have sat us down to wet

Right many a nipperkin!

But arranged as infantry,

And starring face to face,

I shot at him as he at me,

And killed him in his place.

I shot him dead because -

Because he was my foe,

Just so: my foe of course he was ;

That's clear enough; although

He thought he'd 'list, perhaps,

Off-hand-like -just as I -

Was out of work - had sold his traps-

No other reason why.

Yes; quaint and curious war is !

You shoot a fellow down

You'd treat, if met where any bar is , 


\section{Or help half a crown \\ ( Thomas Hardy- 1840-1928)}

In this poem, the irrationality of war has been shown. We kill those innocent people in war who have no grudge against us and might, under different circumstances, show considerable kindness. This poem is included in the EFL Class at Qassim University. Here there is a clear message that as humans, we should believe and work for the promotion of love and peace that lay the foundation of our civilized society. Similarly, in the following stanza of the famous Elegy Written in a Country Churchyard, Gray gives a great message not to be proud of our achievements as every day we are marching towards our grave, so it's wise to be modest .

\section{Elegy Written in a Country Churchyard}

The boast of heraldry, the pomp of pow'r,

And all that beauty, all that wealth e'er gave,

Awaits alike th' inevitable hour,

The paths of glory lead but to the grave

The classical idea of 'memento mori'- a Latin phrase which means every one will have to taste death today or tomorrow is presented here. So, there is hardly any need to develop a sense of superiority because of the material wealth accumulated though right or wrong way. It's better to be down to earth and avoid all forms of rudeness.

\subsection{Short- Stories}

Short-stories also contribute greatly in bringing to the fore important social or moral issues and helping us realize the gravity of certain issues that may otherwise remain in a state of slumber. One such short story is Miss Brill by Mansfield. In this, Miss Brill is a middle-aged, unmarried English tutor in France. Reflections about her daily life reveal that she is alone. The pain and agony of loneliness and social behaviour toward such lonely and tragic persons are worth noting. It's a tragedy of many human beings that they are a misfit in the society. They have no friends, relatives, or sympathisers. It is not the tragedy of Miss Brill alone but there are many women and men like Miss Brill who are living all alone in this otherwise crowded world. A great city becomes a cause for great solitude for some people, but people of our civilized society hardly get any time to share their problems. The Hills Like White Elephant by Hemingway (1899-1961) is also a very famous story in which a girl and a man are shown sitting at a railway station. The man is attempting to convince the woman to get an abortion. But the woman is ambivalent about it. Abortion is illegal but the man is trying his best to get the girl to agree for it, and after abortion, enjoy life as usual.

\subsection{Elizabethan Plays}

Elizabethan plays are even today read and remembered for their magical power of language and ability to highlight the various shades of human nature. There is hardly an iota of doubt that Shakespeare (1564-1616) the great dramatist is one of the most quoted authors of the world. His career spread from the Elizabethan to the Jacobian age. According to Nayar (2009) his work presents human beings in their various roles and businesses. Each of these roles shows particular aspects of what it means to be human: a greedy merchant, a gallant prince, or a jealous lover. 


\subsection{Victorian Fiction}

Fiction writers of the Victorian era gained extreme popularity during their age and enjoy popularity even today. Realism was their preferred form, and their novels were predominantly concerned with social issues. Moral and social codes were major concerns. The three Bronte sisters wrote such novels that formed the heart of mid-Victorian fiction. Their fiction highlighted the wrongs perpetrated on woman (who are described in Charlotte Bronte's Shirley as 'half doll, half angel'), governesses, wives and daughters trapped in claustrophobic families and relationships. In this vast galaxy of writers, Charles Dickens was also a representative writer of the time. He brilliantly exposed the flaws of the age and criticized the social system of his nation. In his famous novel Oliver Twist (1837-39), he narrated the tale of a boy growing up in inimical circumstances, battling poverty, class, the indifference of society and assorted criminals. A well-known Dickens situation is the scene where Oliver, footsore, tired and hungry in the bitter winter, begs of some stage-coach passengers on the way to London, who make him run for half a penny. The novel is a powerful critique of the workhouse era (a result of the Poor Law Amendment Act of 1834) that rendered many children vulnerable to exploitation. Dickens criticizes the education system in these words:

Now what I want is, Facts. Teach these boys and girls nothing but Facts. Facts alone are wanted in life. Plant nothing else and root out everything else. You can only form the minds of reasoning animals on Facts. Facts: nothing else will ever be of any service to them. This is the principle on which I bring up my own children, and this is the principle on which I bring up these children. Stick to Facts, sir!

From the above examples across different genres of literature, it is clear that books are carriers of moral values. So through the teaching of these types of literature, students in EFL/ESL classes would broadly be benefitted in many ways. They would develop the sense of brotherhood, peace, modesty, humility, and honesty.

\section{Discussion and Finding}

Throughout history, it was found that literature is attached to human sorrows, happiness, miseries, triumph, and victories, so on. However, it also has a very profound means of instilling moral values and sharpen individuals' intuition. To pay attention to most prominent writers, suffice to say, Shakespeare, in his plays despite scenes of violence, humanr, ect but his works are considered the mirror of manner and life (Gupta, \& Tiwari, 2017 ). His works dealt with several aspects of life, such as imperfections of human nature. Romeo and Juliet depict the hypocrisy and bigotry of the society where family quarrels, social injustice, and the community's indifference are the harbingers of tragedy for the young couple. The great poet Mathew Arnold departed from the divinely-inspired morality and advocated moral instruction in education. He reported that literature was a source of peoples' aspiration for the highest ideals. These ideas were also found in T. S. Eliot, who believed in the solid moral power of literature.

According to Marx, the literary value of a work of art may result from a particular social condition at a particular period, but it must stand the test of time. The longevity and qualities that engage the interest of people from generation to generation remain the essential criteria for any literature to be labeled as canonical.

It is a well-established fact that the relation between literature and values has changed for the ages. Some critics and scholars say that the two are inseparable, while others do not endorse this view. Moral values and art or ethics and aesthetics are the two sides of the river. It is a fact that literary texts either directly or indirectly disseminate values. In a significant way, literature forms and stabilizes new 
values, norms, and conceptions of better living. Literature is seen as a medium of representing extraliterary norms and values that can generate and construct new values and norms.

In the ever-growing pluralistic society of our times, with numerous cultures, languages, and ethnic groups, it is difficult for educators to decide what values qualify to be taught. 'Today educators are not so worried about "whose values to teach," and are acknowledging this fact that every person needs to acquire certain character attributes and needs to be guided by universal moral values- values that unite all people everywhere because they affirm basic human worth and dignity' Privacy, family, and correspondence.

The teaching of literature everywhere may prove to be a boon to learn the above-mentioned moral values. Values can not be counted but to have more focused on, in this study, the researcher stressed six core moral values which are labeled as attributes of character are 1) Trustworthiness, 2) Respect,3) Responsibility, 4) Justice and Fairness, 5) Caring, 6) Civic Virtue and Citizenship. All these moral values have literary connections. Through the study of literature, these moral values are learned indirectly or directly.

So, literature works on different levels: emotional, ideological, normative, and logical. Special mention must be made of fiction and novels in establishing norms, setting trends, exposing social follies. They are highlighting corruption and producing soothing and allaying effects upon tormented heads and hearts. Morals can be instilled by utilizing various literary forms, such as poems, as moral lessons are taught in most EFL/ESL by reading and clarifying the poems. For example, in 'The Man, He Killed' by Thomas Hardy, or in Short- Stories such as 'Miss Brill' by Mansfield. As well as Elizabethan Plays or Victorian Fiction

From the above examples across different genres of literature, it is proved that literary works have profound values. So through the teaching of these types of literature, students in EFL/ESL classes would broadly be benefitted in many ways. They would develop the sense of brotherhood, peace, modesty, humility, and honesty.

\section{Conclusion}

This study has established the fact that in the teaching of morals the role of literature is unparalleled. Views of great critics like Arnold and Eliot have been discussed in great detail to present the different opinions about morals and cultures. This study documents the objections raised against the appropriateness of literature as a fit medium for providing moral instruction, while also arguing that eminent creations of literature continue to spread universal human values. The aesthetic dimension in literature has been accepted but it has not been accepted as a reason for the denial of moral values in literature. The moral shades in the works of great artists from the Elizabethan to the Victorian to the recent times have been shown to establish the fact that literature provides the best platform to raise our moral standard. The need of moral values and social values in the modern society has also been shown. One unique feature of this study is that it has discussed the cultural function of literature in order to understand the relation between literature and values. Extra literary norms: the power of literature to have norms and values other than the existing values in society (prefiguration), the ability of literature to form new values and norms ( refiguration), and the values and norms which they represent in the medium of fiction ( configuration) have been shown with a purpose to prove the point that literature is always an ambassador of human values. In the latter part of this study, the utility of these moral values in the EFL/ESL classes has been shown. In every EFL/ESL class short stories, poems, drama or novels are taught and this study establishes the moral messages drawn from these. The study also shows how canonical books of literature are endowed with such human and moral values that have withstood the test of time and age. So the need of canonical books has also been 
demonstrated. A special focus has been given to cultural, ethical and social values imbibed via literature. A glimpse of modern society has also been provided to show the need for the teaching of moral values.

\section{References}

Akin, T. (1995). Character Education in America's Schools. Innerchoice Publishing, PO Box 2476, Spring Valley, CA $91979 .$.

Al-Ahdal, A.A.M.H. (2020). Teaching Preparatory School Students in KSA Through Rhymes: An Experimental Study. The Asian ESP Journal, 16(4), 33-56.

Alexander, G. (2004). Sidney's' The Defence of Poesy'and Selected Renaissance Literary Criticism. Penguin UK.

Arnold, M. (1912). Thoughts on Education from Mathew Arnold; in L. Huxley (ed.). London: Smith Elder \& Co. Press.1978, 283.

Baumbach, S., Grabes, H., \& Nünning, A. (2009). Literature and Values. Literature as a medium for representing, disseminating and constructing norms and values. Trier: Wissenschafticher Verlag Trier.

Bloom, A. (2008). Closing of the American mind. Simon and Schuster.

Brady, F., \& Wimsatt, W. (1978). Samuel Johnson: Selected Poetry and Prose. Univ of California Press.

Collins, N.D. (1993). Teaching critical reading through literature. ERIC Clearing house on Reading, English, and Communication.

Eliot, T.S. (1932). Religion and Literature; in Selected Essays. London: Faber \& Faber Ltd.

Eliot, T.S. (1948). Notes towards the definition of cultures. London: Faber \& Faber Ltd.

Gupta, A., \& Tiwari, S.K. (2017). Shakespeare's women characters as a mirror of society. International Journal of English Literature and Social Sciences, 2(6), 239244. https://dx.doi.org/10.24001/ijels.2.6.13

Hassan, A., Kazi, A.S., \& Asmara Shafqat, Z.A. The Impact of Process Writing on the Language and Attitude of Pakistani English Learners. Asian EFL Journal, 27(4.3), 260-277.

Hazhar, R.A., Shaban. K, \& Mohammed, O. (2021). Literary Parody of Russian Communism Harmonizing to George Orwell's Two Novels "Animal Farm" and "Nineteen Eighty Four". International Journal of Language and Literary Studies,3(2), 216-228. https://doi.org/10.36892/ijlls.v3i2.554

Hişmanoğlu, M. (2005). Teaching English through literature. Journal of Language and Linguistic studies, 1(1), 53-66.

Hughes, R. (1993). Culture of complaint: The fraying of America. Oxford University Press, 198 Madison Ave., New York, NY 10016-4314..

Hume, D. (1990). Dialogues concerning natural religion. Penguin UK.

John Dryden," Preface to All for Love ," of Dramatic Poesy and Other Critical Essays , ed. George 
John Keats, Complete Poems, ed. Jack Stillinger (Cambridge, M. A, and London: Havard University Johnson, S. (1977). Selected Poetry and Prose, ed. Frank Brady and WK Wimsatt (Berkeley, 1977), 91 .

Khan, M.S.R., \& Alasmari, A.M. (2018). Literary texts in the EFL classrooms: applications, benefits and approaches. International Journal of Applied Linguistics and English Literature, 7(5), 167179.

Khan, N. (2014). Role of Literature in Moral Development. Department of English and Modern European Languages. University of Allahabad, 2.

Mohaideen, M.S.H., Ismail, H. H., \& Ab Rashid, R. (2020). The Use of Local Literary Texts as Reading Materials in English Language Classrooms: An Analysis of Teachers' Perspectives. International Journal of Learning, Teaching and Educational Research, 19(11), 127144. https://doi.org/10.26803/ijlter.19.11.8

Muhammed, A.A. (2013). The effect of teaching literature on learning English language: A study on EFS (English as a foreign students) and EFL classes. International Journal of Advanced Research in Literature and Education, 1(1), 27-38.

Müller, W.G. (2008). An Ethical Narratology. In Ethics in Culture (pp. 117-130). De Gruyter.

Nayar, P.K. (2009). A short history of English literature. Foundation Books. : Cambridge University Press India Pvt. Ltd Pantić, N. (2006). Moral education through literature. Zbornik Instituta za pedagoska istrazivanja, 38(2), 401-414. https://doi.org/10.2298/ZIPI0602401P

Robbins, W. (1959). The ethical idealism of Mathew Arnold. London: William Heinemann.

Smith, B.H. (1988). Contingencies of value: Alternative perspectives for critical theory. Harvard University Press.

T.S. Eliot, “Burnt Norton“ 1, in Four Quartets (New York : Harcourt, Brace and Company, (1943), 4).

Us Saqlain, N., Shafqat, A., \& Hassan, A. (2020). Perception Analysis of English Language Teachers about Use of Contextualized Text for Teaching ESP. The Asian ESP Journal, 16(5.1), 275-299.

Van, T.T.M. (2009). The relevance of literary analysis to teaching literature in the EFL Classroom. In English Teaching Forum (Vol. 47, No. 3, p. 2). US Department of State. Bureau of Educational and Cultural Affairs, Office of English Language Programs, SA-5, 2200 C Street NW 4th Floor, Washington, DC 20037.

Widdowson, H.G. 1975. Stylistics and the teaching of literature. London: Longman.

Wimsatt, W. (1948). Poetry and Morals: A Relation Reargued. Thought: Fordham University Quarterly, 23(2), 281-299.

Zapf, H. (2006). The state of ecocriticism and the function of literature as cultural ecology. Nature in Literary and Cultural Studies: Transatlantic Conversations on Ecocriticism, 3, 49.

Al-Shibel, A. (2021). Gender differences in classroom interactions and preferences. Journal of Language and Linguistic Studies, 17.

\section{AUTHOR BIODATA}

Mohammad Mujtaba Ahmad earned his M. A. degree in English literature from Lalit Narayana Mithila University (Bihar), India. He engaged himself in comparative study of various languages and went on to complete his Ph.D. from here in 2004. He started his teaching career as a lecturer in the department of English at 
M. R. S. M College, Darbhanga, India, where he taught for more than a decade. He joined as a lecturer in Ministry of Health, K.S.A, in 2004. In 2009 he joined Qassim University and is currently rendering his service as an Assistant Professor in the Department of English Language and Translation, College of Sciences and Arts, Methnab. He is a reputed creative writer and has authored several books, including Songs of Tears and Laughter, a collection of his published poems. He used to compose humorous poems in English, most of which have been published in esteemed Indian dailies like The Hindustan Times, Patna, apart from many magazines. His humorous articles are frequently published in popular newspapers and magazines from Hyderabad, India. He has earned a name for translating into English the articles from Urdu newspaper Akhbar-e-Mashriq published from Kolkata, India. He has also translated many famous Urdu poems into English and published the anthology as Sunny Songs. 